Article

\title{
Chemoselective transfer hydrogenation to nitroarenes mediated by oxygen-implanted $\mathrm{MoS}_{2}$
}

\author{
Chaofeng Zhang a,b, Xu Wang c, Mingrun Li a , Zhixin Zhang a, Yehong Wang a, Rui Si c, Feng Wang a,* \\ a State Key Laboratory of Catalysis, Dalian National Laboratory for Clean Energy, Dalian Institute of Chemical Physics, Chinese Academy of Sciences, \\ Dalian 116023, Liaoning, China \\ b University of Chinese Academy of Sciences, Beijing 100049, China \\ c Shanghai Synchrotron Radiation Facility, Shanghai Institute of Applied Physics, Chinese Academy of Sciences, Shanghai 201204, China
}

\section{A R T I C L E I N F}

\section{Article history:}

Received 3 June 2016

Accepted 11 July 2016

Published 5 September 2016

\section{Keywords:}

$\mathrm{MoS}_{2}$

Coordinative unsaturated Mo

Nitroarene

Transfer hydrogenation

Formate

Heterogeneous catalysis

\begin{abstract}
A B S T R A C T
We present an efficient approach for the chemoselective synthesis of arylamines from nitroarenes and formate over an oxygen-implanted $\mathrm{MoS}_{2}$ catalyst $\left(0-\mathrm{MoS}_{2}\right) .0-\mathrm{MoS}_{2}$ was prepared by incomplete sulfidation and reduction of an ammonium molybdate precursor. A number of Mo-O bonds were implanted in the as-synthesized ultrathin $0-\mathrm{MoS}_{2}$ nanosheets. As a consequence of the different coordination geometries of $\mathrm{O}\left(\mathrm{MoO}_{2}\right)$ and $\mathrm{S}\left(\mathrm{MoS}_{2}\right)$, and lengths of the Mo-O and Mo-S bonds, the implanted Mo-O bonds induced obvious defects and more coordinatively unsaturated (CUS) Mo sites in $\mathrm{O}-\mathrm{MoS}_{2}$, as confirmed by X-ray diffraction, Raman spectroscopy, X-ray photoelectron spectroscopy, high resolution transmission electron microscopy, and extended X-ray absorption fine structure characterization of various $\mathrm{MoS}_{2}$-based materials. O-MoS2 with abundant CUS Mo sites was found to efficiently catalyze the chemoselective reduction of nitroarenes to arylamines.
\end{abstract}

(C) 2016, Dalian Institute of Chemical Physics, Chinese Academy of Sciences. Published by Elsevier B.V. All rights reserved.

\section{Introduction}

Functionalized arylamines [1-3] and their derivatives, such as imines and aromatic azo compounds [4,5], are widely used for the synthesis of dyes, pigments, agrochemicals, pharmaceuticals pesticides, herbicides, and other fine chemicals [6]. Previous studies on the reduction of nitroarenes to anilines have been mainly focused on supported catalysts containing $\mathrm{d}_{6}-\mathrm{d}_{10}$ noble metals and active Ni-based catalysts [7-13]. A crucial issue for the general application of these heterogeneous catalysts for nitro reduction is their selectivity. Different methods, including metal particle size tailoring [14-16], use of alloy nanoparticles [17-19], metal-support cooperative effect regulation [20-22], and solvent and additive screening, have been employed to promote catalyst selectivity. Taking into account the complex synthesis and oxidizable nature of these noble metal catalysts, there is a strong incentive to develop nitroarene reduction processes with efficient and robust catalysts based on non-precious metals [23-30], which can catalyze the reaction in less harmful solvents and do not require many additives.

Compared with catalytic hydrogenation using $\mathrm{H}_{2}$ as the hydrogen source, the convenient and selective transfer hydrogenation process has drawn much attention. As an important hydrogen storage process [31,32], transfer hydrogenation using formic acid provides an attractive alternative to the catalytic hydrogenation of nitroarenes; however, few active heterogeneous catalysts based on non-precious metals have been

\footnotetext{
* Corresponding author. Tel/Fax: +86-411-84379762; E-mail: wangfeng@dicp.ac.cn

This work was supported by the National Natural Science Foundation of China $(21422308,21403216,21273231)$ and Dalian Excellent Youth Foundation (2014J11JH126).
}

DOI: 10.1016/S1872-2067(16)62504-4 | http://www.sciencedirect.com/science/journal/18722067 | Chin. J. Catal., Vol. 37, No. 9, September 2016 
reported [33-35].

For the reduction of nitroarenes with formate, Llusar and co-workers [36] confirmed that coordinative unsaturated (CUS) Mo sites in cubane-type $\left.\left[\mathrm{Mo}_{3} \mathrm{~S}_{4} \mathrm{X}_{3} \text { (dmpe) }\right)_{3}\right]^{+}$clusters played a crucial role in the transformation of formate to the active hydrogen species for nitroarene reduction. Taking into account the similar structural skeleton of $\left[\mathrm{Mo}_{3} \mathrm{~S}_{4} \mathrm{X}_{3}(\mathrm{dmpe})_{3}\right]^{+}$ clusters and $\mathrm{MoS}_{2}$, we postulate that $\mathrm{MoS}_{2}$ could be a robust and easily prepared catalyst for reduction reactions. However, it has been both theoretically and experimentally proved that while the edge sites of $\mathrm{MoS}_{2}$ that have CUS Mo sites are catalytically active, the mostly exposed basal planes are inactive [37-39]. Chemical and mechanical exfoliation methods can increase the number of active sites [40-42]. Therefore, in light of the high-aspect-ratio architecture of $\mathrm{MoS}_{2}$ nanosheets, a novel strategy should be developed to change the mostly exposed $\mathrm{MoS}_{2}$ basal planes to be catalytically active.

It is anticipated that the fractional replacement of $\mathrm{S}$ with $\mathrm{O}$ in the $\mathrm{MoS}_{2}$ crystalline lattice may create extra CUS Mo sites because the ligand geometries of $\mathrm{O}\left(\mathrm{MoO}_{2}\right)$ and $\mathrm{S}\left(\mathrm{MoS}_{2}\right)$, and the lengths of the Mo-O and Mo-S bonds are remarkably different $[43,44]$, which could induce lattice distortion and defects. However, it is rather challenging to obtain such a structure via post-modification, because perfect $\mathrm{MoS}_{2}$ basal planes consisting of closed shell Mo centers and strong Mo-S bonds can either endure post-modification or will be completely changed. Therefore, one possible way to implant 0 into the $\mathrm{MoS}_{2}$ lattice should be via bulk synthesis.

Encouraged by previous studies of $\mathrm{MoS}_{2}$ in photonic and electrocatalytic applications [45-48], we successfully synthesized oxygen-implanted $\mathrm{MoS}_{2}$ (designated as $\mathrm{O}-\mathrm{MoS}_{2}$ ) via incomplete sulfidation and reduction of a molybdate precursor $\left(\left[\mathrm{Mo}_{7} \mathrm{O}_{24}\right]^{6-}\right)$. The presence of deliberately left Mo-O or $\mathrm{Mo}=0$ bonds in the $\mathrm{O}-\mathrm{MoS}_{2}$ lattice was confirmed by XPS and Raman spectroscopy characterization. HRTEM observations revealed that the as-synthesized $0-\mathrm{MoS}_{2}$ had a coiled nanosheet morphology with highly distorted crystal lattice and defect-rich zones on its basal planes. EXAFS indicated the existence of four-fold and five-fold CUS Mo sites. As a result of the lattice defects, abundant active CUS Mo sites existed in the $\mathrm{O}-\mathrm{MoS}_{2}$, which functioned as active sites in the hydrogen transfer reduction of nitroarenes with formate in water.

\section{Experimental}

\subsection{Materials}

All chemicals were of analytical grade and used as obtained without further purification.

\subsection{Catalyst preparation}

The preparation of the $\mathrm{O}-\mathrm{MoS}_{2}$ was adapted from Xie et al [46]. Typically, $3.70 \mathrm{~g}\left(\mathrm{NH}_{4}\right)_{6} \mathrm{Mo}_{7} \mathrm{O}_{24} \cdot 4 \mathrm{H}_{2} \mathrm{O}$ ( $3 \mathrm{mmol}$, AHM) and $6.85 \mathrm{~g}$ thiourea $(90 \mathrm{mmol})$ were dissolved in $105 \mathrm{~mL}$ distilled water and placed in an autoclave. The autoclave was tightly sealed in air and then placed in an oven thermally stabilized at $180^{\circ} \mathrm{C}$ for $24 \mathrm{~h}$, after which the autoclave was removed from the oven and allowed to naturally cool to room temperature. The solid product was centrifuged, washed with distilled water and ethanol, and then dried at $60{ }^{\circ} \mathrm{C}$ under vacuum. The final dry solid was $\mathrm{O}-\mathrm{MoS}_{2}$. $\mathrm{O}-\mathrm{MoS}_{2}-\mathrm{Ar}$ was also prepared by treating $\mathrm{O}-\mathrm{MoS}_{2}$ in an Ar flow at $250^{\circ} \mathrm{C}$ for $3 \mathrm{~h}$.

The chemical exfoliation of commercial $2 \mathrm{H}-\mathrm{MoS}_{2}$ (designated as $\mathrm{ceMoS}_{2}$ ) was adapted from Chou et al [49]. $700 \mathrm{mg}$ of $2 \mathrm{H}-\mathrm{MoS}_{2}$ powder was immersed in $10 \mathrm{~mL}$ of $n$-butyllithium $(1.6$ $\mathrm{mol} / \mathrm{L}$ in hexane) and stirred for $48 \mathrm{~h}$ under Ar protection. After the stirring, $20 \mathrm{~mL}$ hexane was added to the mixture, and $0.36 \mathrm{~mL} \mathrm{H}_{2} \mathrm{O}$ was then added dropwise over $10 \mathrm{~min}$ under $\mathrm{Ar}$ flow. After $0.5 \mathrm{~h}$, a further $200 \mathrm{~mL}$ of $\mathrm{H}_{2} \mathrm{O}$ was added to the mixture. The mixture was then sonicated for $2 \mathrm{~h}$ to achieve exfoliation. The ceMoS2 nanosheets were then centrifuged and washed with water and ethanol five times, and the final products were obtained after vacuum drying at room temperature.

$\mathrm{MoO}_{3} / 2 \mathrm{H}-\mathrm{MoS}_{2}\left(\mathrm{MoO}_{3}, 5 \mathrm{wt} \%\right)$ was prepared by impregnating $2 \mathrm{H}-\mathrm{MoS}_{2}(1.0 \mathrm{~g})$ in $8 \mathrm{~mL}$ of AHM solution $(61 \mathrm{mg})$. The extra solvent was evaporated on a metal heating plate at 120 ${ }^{\circ} \mathrm{C}$. The obtained dry solid was then annealed at $500{ }^{\circ} \mathrm{C}$ for $2 \mathrm{~h}$ in Ar flow (30 mL/min). $\mathrm{MoO}_{2} / 2 \mathrm{H}-\mathrm{MoS}_{2}\left(\mathrm{MoO}_{2}, 5 \mathrm{wt} \%\right)$ was obtained by adding $2 \mathrm{H}-\mathrm{MoS}_{2}(1.0 \mathrm{~g})$ to $8 \mathrm{~mL}$ of phosphomolybdic acid solution $(7.5 \mathrm{~g} / \mathrm{L})$. The extra solvent was evaporated on a metal heating plate at $120^{\circ} \mathrm{C}$. The obtained dry solid was then reduced at $500{ }^{\circ} \mathrm{C}$ for $2 \mathrm{~h}$ in a $\mathrm{H}_{2} / \mathrm{N}_{2}$ (1/9) flow (30 mL/min) [28]. Partially oxidized $2 \mathrm{H}-\mathrm{MoS}_{2}\left(2 \mathrm{H}-\mathrm{MoS}_{2}-\mathrm{O}_{2}\right)$ was prepared by treating $2 \mathrm{H}-\mathrm{MoS}_{2}$ in an air flow $(30 \mathrm{~mL} / \mathrm{min})$ at $400{ }^{\circ} \mathrm{C}$ for $0.5 \mathrm{~h}$.

\subsection{Characterization}

X-ray diffraction (XRD) analyses were conducted on a Rigaku D/Max 3400 powder diffraction system with $\mathrm{Cu} K_{\alpha}$ radiation $(\lambda=1.542 \AA)$. X-ray photoelectron spectroscopy (XPS) measurements were carried out on a VGESCALAB MK2 spectrometer equipped with an $\mathrm{Al} K_{\alpha} \mathrm{X}$-ray source $(h v=1486.6 \mathrm{eV})$ operated at a voltage of $12.5 \mathrm{kV}$. The binding energy (BE) was calibrated with the $\mathrm{C} 1 s$ signal $(284.6 \mathrm{eV})$ as a reference. Raman spectra were recorded on a micro-Raman spectrometer (Renishaw) equipped with a CCD detector using a He/Ne laser with a wavelength of $532 \mathrm{~nm}$. High-resolution transmission electron microscopy (HRTEM) was carried out on an FEI Tecnai F30 electron microscope at an accelerating voltage of $300 \mathrm{kV}$.

X-ray absorption fine structure (XAFS) spectral measurements at the Mo K-edge $\left(E_{0}=20000 \mathrm{eV}\right)$ were performed at beamline BL14W1 of the Shanghai Synchrotron Radiation Facility (SSRF) operated at $3.5 \mathrm{GeV}$ under "top-up" mode with a constant current of $240 \mathrm{~mA}$. The XAFS data were recorded under transmission mode with ion chambers. The energy was calibrated according to the absorption edge of pure Mo foil. Athena and Artemis codes were used to extract the data and fit the profiles. For the X-ray absorption near edge structure (XANES) part, the experimental absorption coefficients as function of energy $\mu(E)$ were processed using background subtraction and normalization procedures, and are reported as "normalized absorptions". For the extended X-ray absorption fine 
structure (EXAFS) part, the Fourier transformed (FT) data in $R$ space were analyzed by applying a $\mathrm{MoS}_{2}$ model for the Mo-S or Mo-Mo shell. The passive electron factors, $S_{0}{ }^{2}$, were determined by fitting the experimental Mo foil data and fixing the Mo-Mo coordination number $(\mathrm{CN})$ as $8+6$, then fixed for further analysis of the investigated samples. The parameters describing the electronic properties (e.g., correction to the photoelectron energy origin, $E_{0}$ ) and local structural environment, including CN, bond distance (R), and Debye Waller (D.W.) factor around the absorbing atoms, were allowed to vary during the fitting process.

The CUS Mo sites of MoS2 were probed and quantitatively analyzed by temperature-programmed desorption of ammonia ( $\mathrm{NH}_{3}$-TPD). A few milligrams of $\mathrm{MoS}_{2}$ sample were loaded into a quartz tubular reactor, which was heated in a vertical electronic furnace. The desorption gas mixture was analyzed with an online mass spectrometer (THERMOStar gas analysis system). The sample was initially pretreated at $100^{\circ} \mathrm{C}$ under an $\mathrm{Ar}$ gas flow ( $30 \mathrm{~mL} / \mathrm{min}$ ) for $1 \mathrm{~h}$ to remove adsorbed impurities, and then cooled to room temperature. The flow gas was then switched to ammonia gas (99.9\%) for $30 \mathrm{~min}$ at room temperature, and then back to Ar gas. The reactor temperature was increased to $400{ }^{\circ} \mathrm{C}$ at a ramp rate of $10{ }^{\circ} \mathrm{C} / \mathrm{min}$. An $\mathrm{m} / z=17$ signal was recorded for $\mathrm{NH}_{3}$ and $\mathrm{HO}^{*}$ from $\mathrm{H}_{2} \mathrm{O}$. The pure $\mathrm{NH}_{3}$ mass signal was the value obtained after subtraction of the $\mathrm{HO}^{*}$ mass signal from the $m / z=17\left(\mathrm{NH}_{3}\right.$ and $\mathrm{HO}^{*}$ ) signal, based on the reference mass spectrum of $\mathrm{H}_{2} \mathrm{O}(\mathrm{m} / \mathrm{z}=18)$. The quantitative results were calculated by referring to an ammonia standard curve.

\subsection{Catalytic reactions and product analyses}

For the catalytic reactions, typically, $0.5 \mathrm{mmol}$ nitroarene, $2.5 \mathrm{~mL}$ solvent, $189 \mathrm{mg}$ ammonium formate ( $3.0 \mathrm{mmol}$ ), and catalyst $(20 \mathrm{mg}$ ) were added to a $15 \mathrm{~mL}$ pressure bottle reactor (maximum pressure 1.0 $\mathrm{MPa}$, the typical reaction pressure was less than $0.4 \mathrm{MPa}$ ) with magnetic stirring. The atmosphere in the reactor was then replaced with Ar gas three times and tightly sealed. The reactor was placed in an oil bath preheated to the desired temperature. After the set reaction time, the reactor was quenched with cold water and the reaction mixture was diluted with $7.5 \mathrm{~mL}$ ethanol. The ethanol solution was analyzed by GC and GC-MS.

\section{Results and discussion}

\subsection{General characterization}

Two distinct peaks were observed at the low-angle region of the XRD pattern of the synthesized $0-\mathrm{MoS}_{2}$, with $d$-spacings of $9.52 \AA$ and $4.76 \AA$, respectively (Figure 1), indicating the formation of a new lamellar structure with enlarged interlayer spacing. Thermal treatment of $0-\mathrm{MoS}_{2}$ in $\mathrm{Ar}$ gas at $250{ }^{\circ} \mathrm{C}$ for 3 $\mathrm{h}$ caused the XRD pattern of the material $\left(\mathrm{O}-\mathrm{MoS}_{2}-\mathrm{Ar}\right)$ to resemble that of commercial 2H-MoS 2 (JCPDS Card No. 37-1492), signifying that the thermal treatment transformed the $\mathrm{O}-\mathrm{MoS}_{2}$. It should be noted that no molybdenum oxide $\left(\mathrm{MoO}_{2}\right.$ or $\left.\mathrm{MoO}_{3}\right)$

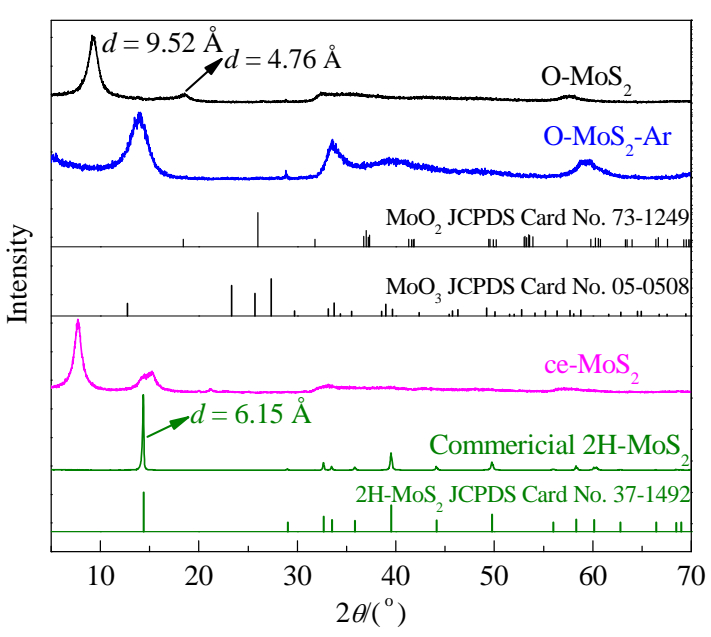

Fig. 1. XRD patterns of the $\mathrm{MoS}_{2}$ materials.

crystallites were present in $\mathrm{O}-\mathrm{MoS}_{2}$ according to the XRD results. EDX analysis showed that the 0 content of the $\mathrm{O}-\mathrm{MoS}_{2}$ was 3.7 atom\%. The TPD-MS results (Figure 2) showed that no lattice oxygen species were released from the $0-\mathrm{MoS}_{2}$ as $\mathrm{O}_{2}$ or $\mathrm{SO}_{2}$ in the Ar flow below $250{ }^{\circ} \mathrm{C}$.

XPS was carried out to investigate the chemical composition of the sample. As shown in Figure 3(a), two characteristic peaks arising from Mo $3 d_{5 / 2}$ and Mo $3 d_{3 / 2}$ orbitals were located at 229.1 and $232.2 \mathrm{eV}$ in the spectra, respectively, suggesting the dominance of $\mathrm{Mo}^{\text {(IV) }}$ in the product [39]. In contrast, the $\mathrm{S} 2 p$ region (Figure $3(\mathrm{~b})$ ) primarily exhibited a single doublet with a $2 p_{3 / 2}$ peak at $161.7 \mathrm{eV}$, which is consistent with -2 oxidation state of sulfur [39]. Furthermore, as shown in Figure 3(c), the observed $01 \mathrm{~s}$ peak located at $530.7 \mathrm{eV}$ corresponded to the bonding of oxygen with Mo ions [50], suggesting the existence of Mo(IV)-O bonds and thus verifying the successful incorporation of oxygen. The peak located at $532.0 \mathrm{eV}$ can be attributed to adsorbed water. Because the molybdate precursor contained $\mathrm{Mo}^{6+}$, it is very reasonable that the sulfidation and reduction process was incomplete and some Mo-O bonds remained in the $0-\mathrm{MoS}_{2}$ sample.

More bonding information was revealed by the Raman spectra (Figure 4). The peaks at 376 and $401 \mathrm{~cm}^{-1}$ arose from

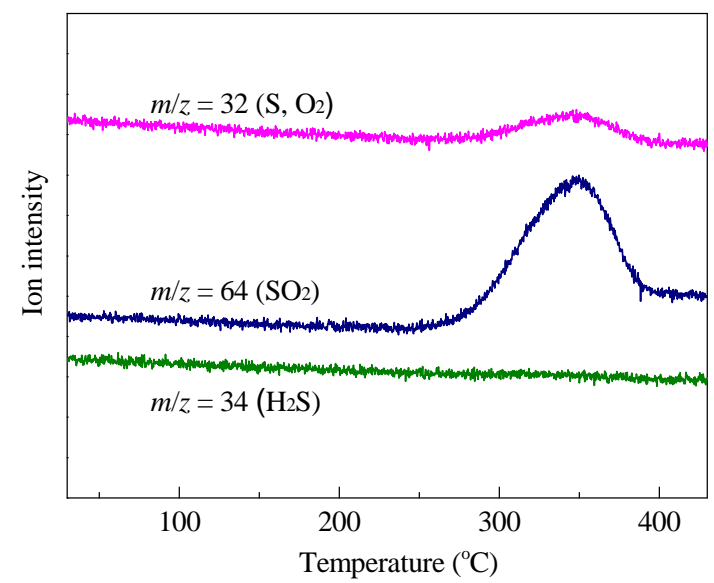

Fig. 2. TPD profiles of the $0-\mathrm{MoS}_{2}$ in Ar flow. 

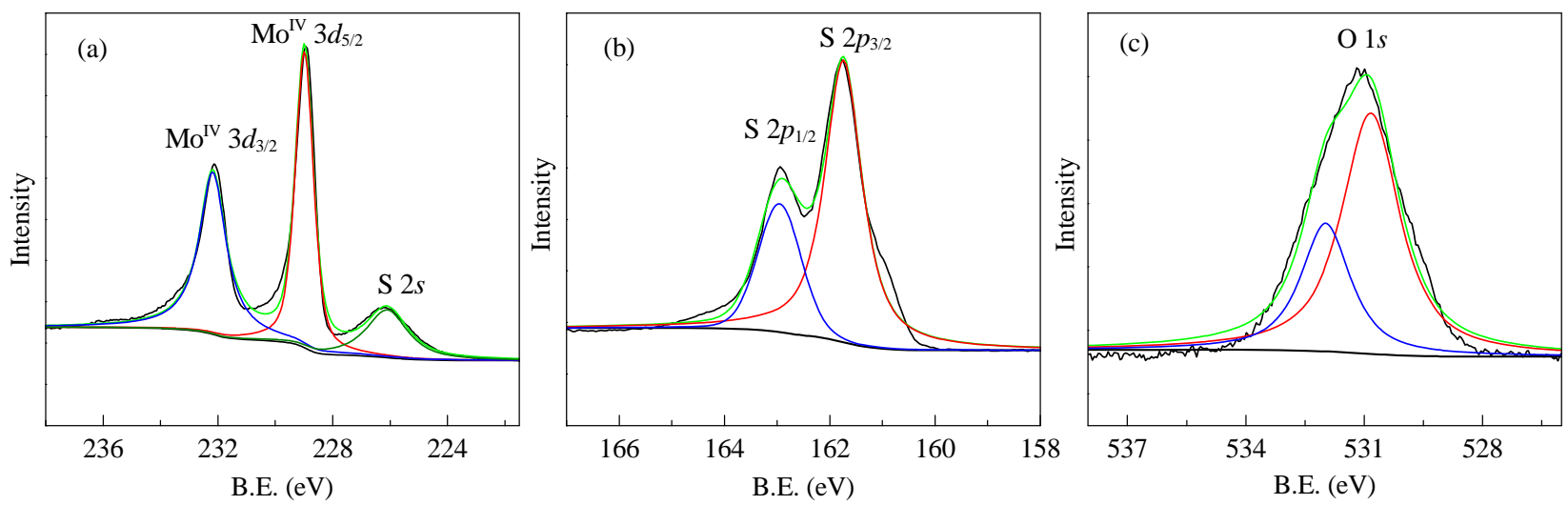

Fig. 3. XPS spectra showing the binding energy of molybdenum (a), sulfur (b), and oxygen (c) in the $0-\mathrm{MoS}_{2}$.

the $\mathrm{E}_{2 \mathrm{~g}}^{1}$ and $\mathrm{A}_{1 \mathrm{~g}}$ vibrational modes of the Mo-S bonds, respectively, which are present in both $2 \mathrm{H}-\mathrm{MoS}_{2}$ and $0-\mathrm{MoS}_{2}[51,52]$. The peaks at 281 and $335 \mathrm{~cm}^{-1}$, attributed to the $\mathrm{B}_{2 \mathrm{~g}}$ and $\mathrm{B}_{1 \mathrm{~g}}$ vibrational modes of $\delta(\mathrm{Mo}=0)$ and $\delta\left(\mathrm{OMo}_{3}\right)$ respectively, only present in $0-\mathrm{MoS}_{2}$ [53]. Together with the peak at $662 \mathrm{~cm}^{-1}$

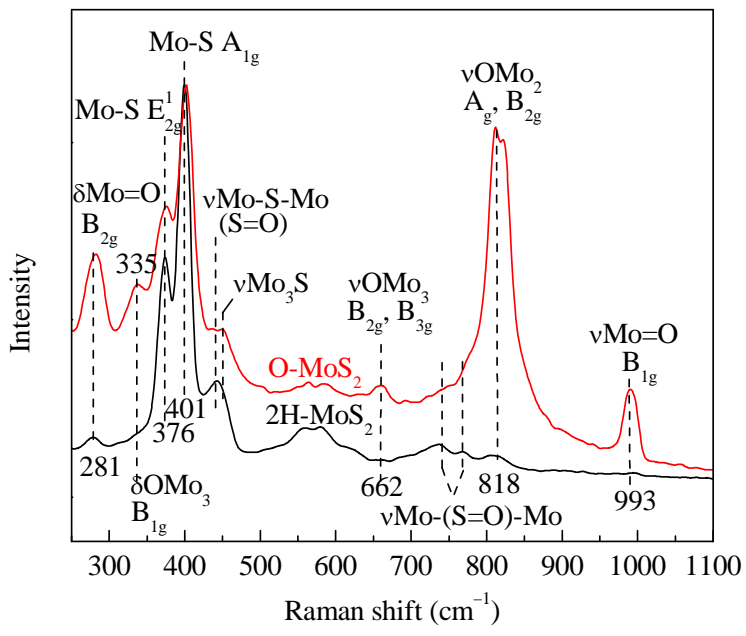

Fig. 4. Raman spectra of $\mathrm{O}-\mathrm{MoS}_{2}$ and $2 \mathrm{H}-\mathrm{MoS}_{2}$.
(OMo3 units) and strong bands at $818 \mathrm{~cm}^{-1}$ (Mo-0-Mo bonds) and $993 \mathrm{~cm}^{-1}[\mathrm{v}(\mathrm{Mo}=0)]$ [53], these results confirm that Mo-O bonds existed in $\mathrm{O}_{-} \mathrm{MoS}_{2}$ with bonding types of $\mathrm{Mo}=\mathrm{O}, \mathrm{OMo}_{3}$, and $\mathrm{Mo}-\mathrm{O}-\mathrm{Mo}$. No $\mathrm{MoO}_{2}$ phase appeared in the XRD pattern of the $0-\mathrm{MoS}_{2}$, which implied a high dispersion of oxygen ions in the $\mathrm{O}-\mathrm{MoS}_{2}$ structure.

The morphology of the $\mathrm{MoS}_{2}$ materials was observed by HRTEM. Both 2H-MoS 2 (Figure 5(b)) and ceMoS 2 (Figure 5(d)) preferentially exposed basal planes with ordered Mo and $\mathrm{S}$ atoms, indicating a well-crystallized phase. In contrast, $\mathrm{O}-\mathrm{MoS}_{2}$ featured twisted ultrathin sheets, the atomic surface of which was short-range ordered but long-range disordered, as illustrated by the high-resolution image shown in Figure 5(f). Except for the lattice-distorted zones, a number of subnano-sized defected zones with additional edge sites were also observed on $\mathrm{O}-\mathrm{MoS}_{2}$. The thermal treatment of $\mathrm{O}-\mathrm{MoS}_{2}$ in Ar flow at 250 ${ }^{\circ} \mathrm{C}$ reformed the $\mathrm{O}-\mathrm{MoS}_{2}$, and consequently, the $\mathrm{O}-\mathrm{MoS}_{2}-\mathrm{Ar}$ surface became ordered (Figure 5(h)).

Different from XRD, which is used to determine the crystal structure of well-crystallized materials, XAFS is very effective for determining the short-range local structure of heterogeneous catalysts [54-56]. As shown in Figure 5, 0-MoS2 was

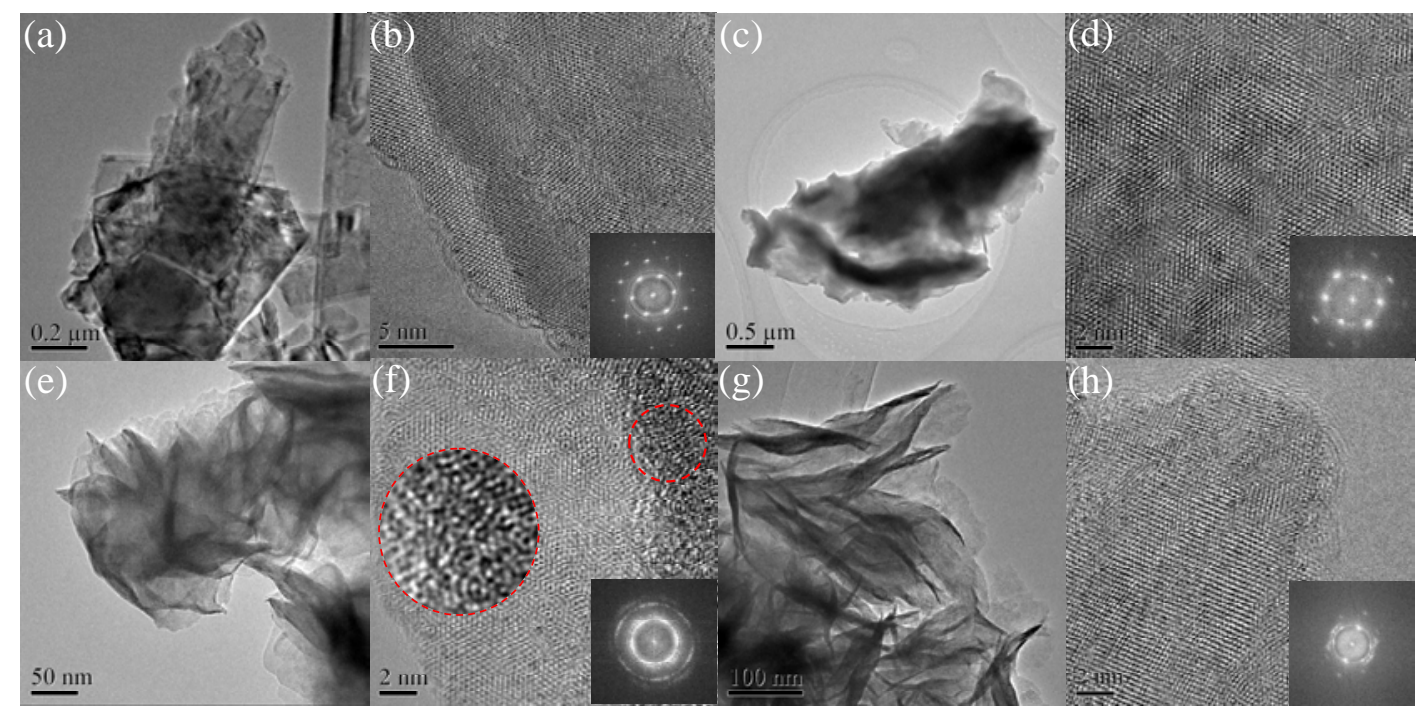

Fig. 5. TEM and HRTEM images of $2 \mathrm{H}-\mathrm{MoS}_{2}(\mathrm{a}, \mathrm{b}), \mathrm{ceMoS}_{2}(\mathrm{c}, \mathrm{d}), \mathrm{O}-\mathrm{MoS}_{2}(\mathrm{e}, \mathrm{f})$, and O-MoS$-\mathrm{Ar}$ (g, h). 

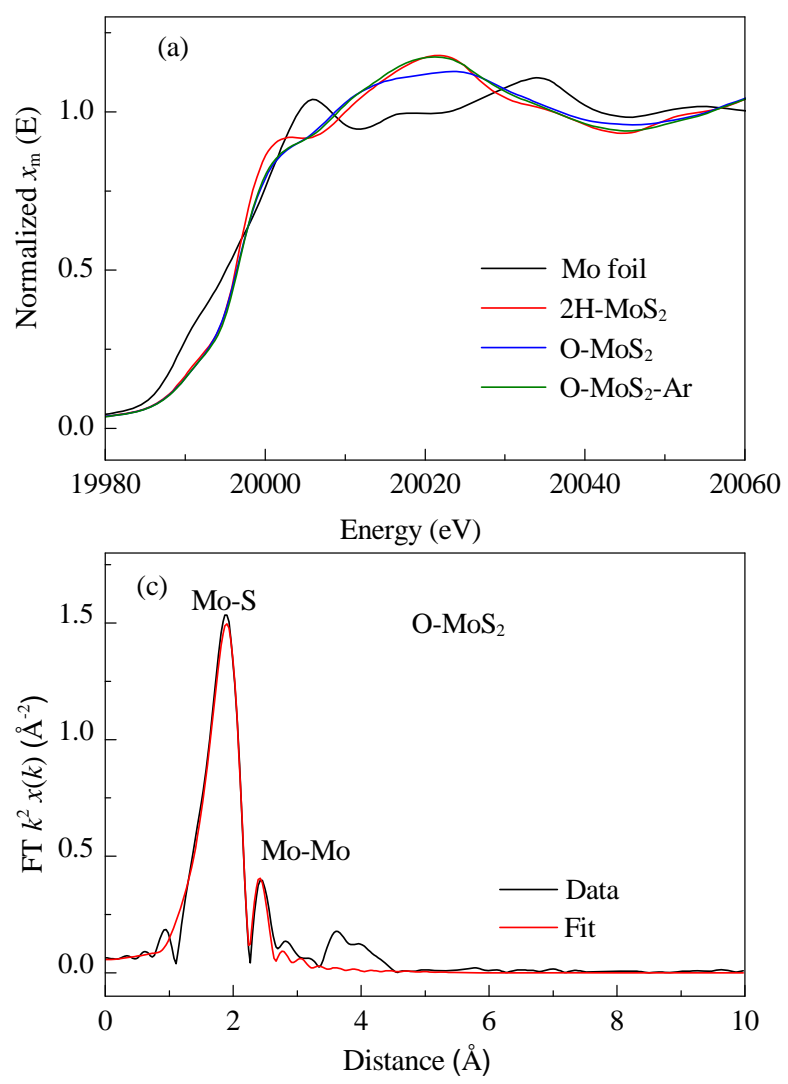
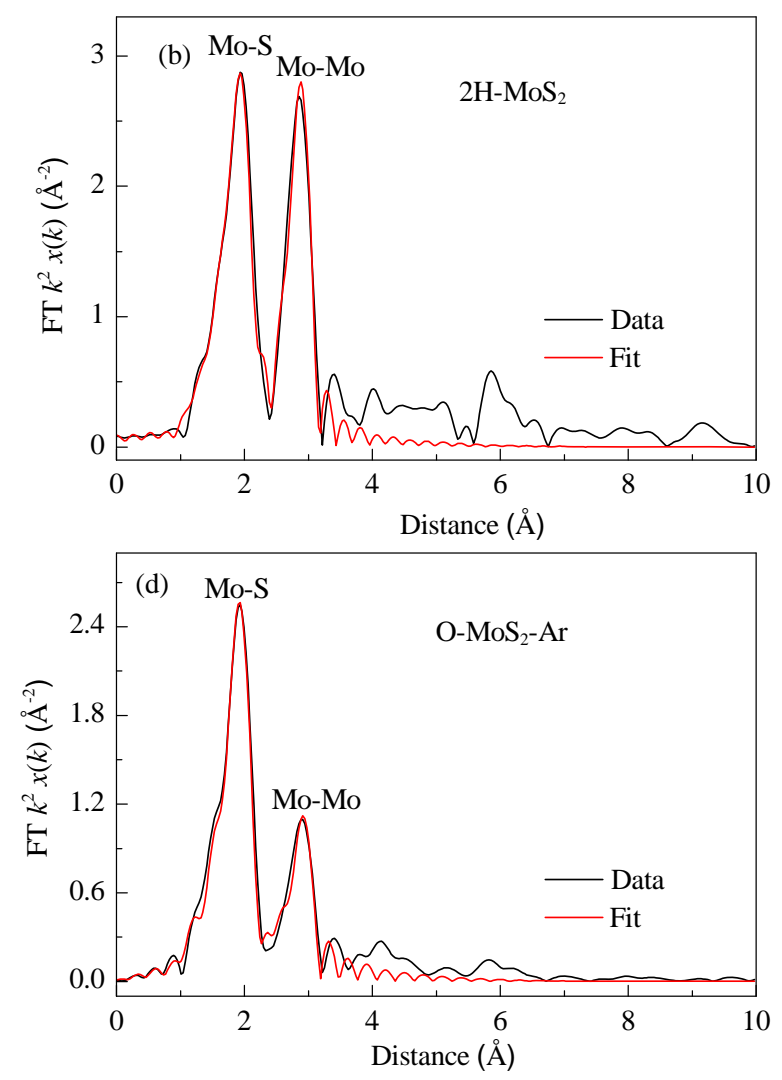

Fig. 6. Normalized E space spectra (a) of the Mo-based materials and EXAFS R space spectra of 2H-MoS 2 (b), $\mathrm{O}-\mathrm{MoS} 2$ (c), and $\mathrm{O}-\mathrm{MoS} 2-\mathrm{Ar}$ (d).

short-range ordered but long-range disordered. To obtain more structural information about the $\mathrm{MoS}_{2}$-based materials, the EXAFS fitting method was adopted to evaluate the change in the coordination shell of the Mo atoms in the $0-\mathrm{MoS}_{2}$ crystal structure.

It can be seen from Figure 6(a) that the Mo in all analyzed samples $\left(2 \mathrm{H}-\mathrm{MoS}_{2}, \mathrm{O}-\mathrm{MoS}_{2}, \mathrm{O}-\mathrm{MoS}_{2}-\mathrm{Ar}\right)$ was more oxidized than Mo foil $\left(\mathrm{Mo}^{0}\right)$, which is in good agreement with the $\mathrm{MoS}_{2}$ model. For the EXAFS part, Table 1 shows that the Mo-Mo distance $(R)$ in the structure of $2 \mathrm{H}-\mathrm{MoS}_{2}$ was $3.17 \AA$, with a coordination number $(\mathrm{CN})$ of $6.9 \pm 1.3$, which are very close to the theoretical values $\left(R_{\mathrm{Mo}-\mathrm{Mo}}=3.15 \AA\right.$, $\left.\mathrm{CN}_{\text {Mo-Mo }}=6\right)$ and show that the commercial $2 \mathrm{H}-\mathrm{MoS}_{2}$ had a well-crystallized phase. However, when oxygen (3.7 atom\% according to the EDX results) was implanted into the $\mathrm{MoS}_{2}$ structure via the hydrothermal synthesis method, the Mo-Mo distance decreased from $3.15 \AA$ to $2.77 \AA$. This shows that the layered structure changed essentially, which was reflected by the differences in the XRD pat-

Table 1

EXAFS fitting results of Mo-based catalysts.

\begin{tabular}{lccccc}
\hline \multirow{2}{*}{ Sample } & \multicolumn{2}{c}{ Mo-S } & & \multicolumn{2}{c}{ Mo-Mo } \\
\cline { 2 - 3 } \cline { 5 - 6 } & $R / \AA$ & $C N$ & & $R / \AA$ & $C N$ \\
\hline \multirow{2}{*}{ Mo foil } & - & - & & $2.72 \pm 0.00$ & 8 \\
& & & & $3.14 \pm 0.01$ & 6 \\
$2 \mathrm{H}-M o S_{2}$ & $2.40 \pm 0.00$ & $5.2 \pm 0.5$ & & $3.17 \pm 0.00$ & $6.9 \pm 1.3$ \\
O-MoS $_{2}$ & $2.41 \pm 0.01$ & $4.2 \pm 0.5$ & & $2.77 \pm 0.02$ & $0.6 \pm 0.2$ \\
O-MoS $_{2}-\mathrm{Ar}$ & $2.40 \pm 0.01$ & $4.7 \pm 0.4$ & & $3.16 \pm 0.01$ & $2.9 \pm 1.1$ \\
\hline
\end{tabular}

$R$-Distance; CN-Coordination number. terns of $\mathrm{O}-\mathrm{MoS}_{2}$ and $2 \mathrm{H}-\mathrm{MoS}_{2}$. The $\mathrm{CN}$ of Mo-Mo in $\mathrm{O}-\mathrm{MoS}_{2}$ changed more obviously to $0.6 \pm 0.2$, which indicates that the Mo-Mo structure on the second shell almost disappeared and that $\mathrm{O}-\mathrm{MoS}_{2}$ had a high degree of disorder, as confirmed by HRTEM (Figure 5(f)). When O-MoS2 was treated in $\mathrm{Ar}$ at $250^{\circ} \mathrm{C}$, the Mo-Mo distance in the resulting $\mathrm{O}-\mathrm{MoS}_{2}-\mathrm{Ar}$ returned to $3.16 \pm 0.01 \AA$, which showed that the thermal treatment not only reformed the interlayer spacing (Figure 1, O-MoS2 and $\mathrm{O}-\mathrm{MoS}_{2}-\mathrm{Ar}$ ) but also increased the crystallinity of the layer structure. Meanwhile, the $\mathrm{CN}$ of Mo-Mo in $\mathrm{O}-\mathrm{MoS}_{2}-\mathrm{Ar}$ was $2.9 \pm 1.1$, which also indicated the existence of structural disorder. In the $\mathrm{MoS}_{2}$-based materials, the Mo-S distance almost conformed to the theoretical value (Mo-S bond, $2.41 \AA$ ), and the $\mathrm{CN}$ of the Mo-S structure in each material was 4.2-5.2 with a lower fluctuation than that of the Mo-Mo structure. These results show that the interaction between Mo and S in the present system was strong and stable. Given that the oxygen content of the $0-\mathrm{MoS}_{2}$ was almost $\sim 3$ atom\% (EDX results) and the $\mathrm{CN}$ was $4.2 \pm 0.5$ for the Mo-S structure and $0.6 \pm 0.2$ for the Mo-Mo structure in $\mathrm{O}-\mathrm{MoS}_{2}, \mathrm{O}-\mathrm{MoS}_{2}$ was expected to contain more CUS Mo sites than $2 \mathrm{H}-\mathrm{MoS}_{2}$ or $\mathrm{O}-\mathrm{MoS}_{2}-\mathrm{Ar}$. These CUS Mo sites were thought to exist as four-fold and five-fold coordinated Mo species.

\subsection{Probe catalytic reactions for the CUS Mo sites}

The reduction of nitrobenzene with ammonium formate $\left(\mathrm{HCOONH}_{4}\right)$ was used as a probe reaction to examine the 
Table 2

Reduction of nitrobenzene to aniline a

\begin{tabular}{|c|c|c|c|}
\hline Entry & Catalyst & Solvent & GC yield of aniline $\mathrm{g}(\%)$ \\
\hline 1 & $2 \mathrm{H}-\mathrm{MoS}_{2}$ & $\mathrm{H}_{2} \mathrm{O}$ & $<0.5$ \\
\hline 2 & $\mathrm{MoS}_{3}$ & $\mathrm{H}_{2} \mathrm{O}$ & 4.1 \\
\hline 3 & $\operatorname{ceMoS}_{2}$ & $\mathrm{H}_{2} \mathrm{O}$ & 54.9 \\
\hline 4 & $\mathrm{O}-\mathrm{MoS}_{2}$ & $\mathrm{H}_{2} \mathrm{O}$ & $>99$ \\
\hline 5 & no catalyst & $\mathrm{H}_{2} \mathrm{O}$ & $<0.5$ \\
\hline $6 \mathrm{~b}$ & $\mathrm{O}-\mathrm{MoS}_{2}$ & $\mathrm{H}_{2} \mathrm{O}$ & 0 \\
\hline $7^{c}$ & $\mathrm{O}-\mathrm{MoS}_{2}$ & $\mathrm{H}_{2} \mathrm{O}$ & $<0.5$ \\
\hline 8 & $\mathrm{O}-\mathrm{MoS}_{2}$ & ethanol & 11.7 \\
\hline 9 & $\mathrm{O}-\mathrm{MoS}_{2}$ & DMF & 14.2 \\
\hline 10 & $\mathrm{O}-\mathrm{MoS}_{2}$ & DMSO & 82.0 \\
\hline 11 & $\mathrm{MoO}_{2}$ & $\mathrm{H}_{2} \mathrm{O}$ & 0 \\
\hline 12 & $\mathrm{MoO}_{3}$ & $\mathrm{H}_{2} \mathrm{O}$ & 0 \\
\hline 13 & $\mathrm{MoO}_{3} / 2 \mathrm{H}-\mathrm{MoS}_{2}$ & $\mathrm{H}_{2} \mathrm{O}$ & 0 \\
\hline 14 & $\mathrm{MoO}_{2} / 2 \mathrm{H}-\mathrm{MoS}_{2}$ & $\mathrm{H}_{2} \mathrm{O}$ & 0 \\
\hline 15 & $\mathrm{O}-\mathrm{MoS}_{2}-\mathrm{Ar}$ & $\mathrm{H}_{2} \mathrm{O}$ & 0.9 \\
\hline 16 & $2 \mathrm{H}-\mathrm{MoS}_{2}-\mathrm{O}_{2}$ & $\mathrm{H}_{2} \mathrm{O}$ & 0 \\
\hline $17^{\mathrm{d}}$ & $\mathrm{O}-\mathrm{MoS}_{2}$ & $\mathrm{H}_{2} \mathrm{O}$ & 76.1 \\
\hline $18^{\mathrm{e}}$ & no & $\mathrm{H}_{2} \mathrm{O}$ & 76.2 \\
\hline 19 & $\mathrm{O}-\mathrm{MoS}_{2} \mathrm{f}$ & $\mathrm{H}_{2} \mathrm{O}$ & $>99$ \\
\hline
\end{tabular}

a Reaction conditions: nitrobenzene $0.5 \mathrm{mmol}^{\mathrm{HCOONH}} \mathrm{H}_{4} 3.0 \mathrm{mmol}^{\mathrm{H}} \mathrm{H}_{2} \mathrm{O}$ $2.5 \mathrm{~mL}$, catalyst $20 \mathrm{mg}, \mathrm{Ar}, 130{ }^{\circ} \mathrm{C}, 3 \mathrm{~h}$. ${ }^{\mathrm{b}}$ Without $\mathrm{HCOONH}_{4}{ }^{\mathrm{c}}{ }^{\mathrm{P}}\left(\mathrm{H}_{2}\right) 0.4$ MPa. ${ }^{d} 1$ h. e Hot filtration experiment for another 100-min reaction after $1 \mathrm{~h}$ reaction. ${ }^{\mathrm{f}}$ Reuse of $\mathrm{O}-\mathrm{MoS}_{2}$ for the fourth time. ${ }^{\mathrm{g}}$ Aniline was the only product.

change in the CUS Mo sites in the different $\mathrm{MoS}_{2}$ materials [36]. The nitrobenzene conversion over $2 \mathrm{H}-\mathrm{MoS}_{2}$ and $\mathrm{MoS}_{3}$ was $0.5 \%$ and $4.1 \%$, respectively (Table 2 , entries 1 and 2 ). Reaction over ceMoS 2 offered a $54.9 \%$ aniline yield (entry 3). Unexpectedly, reaction over $0-\mathrm{MoS}_{2}$ gave $>99 \%$ aniline yield within $3 \mathrm{~h}$ (entry 4). Both $\mathrm{O}-\mathrm{MoS}_{2}$ and $\mathrm{HCOONH}_{4}$ were indispensable for the reaction (entries 5 and 6). Reaction with $\mathrm{H}_{2}$ as reductant gave no product (entry 7), which implies that the reduction involves active hydrogen species from $\mathrm{HCOONH}_{4}$, not molecular $\mathrm{H}_{2}$. Water was the best solvent among water, ethanol, DMF, and DMSO (entries 8-10). This could be because $\mathrm{HCOONH}_{4}$ was best ionized in water, which is regarded as the key step during the dehydrogenation of formate to the active $\mathrm{H}^{*}$ species $[36,57]$.

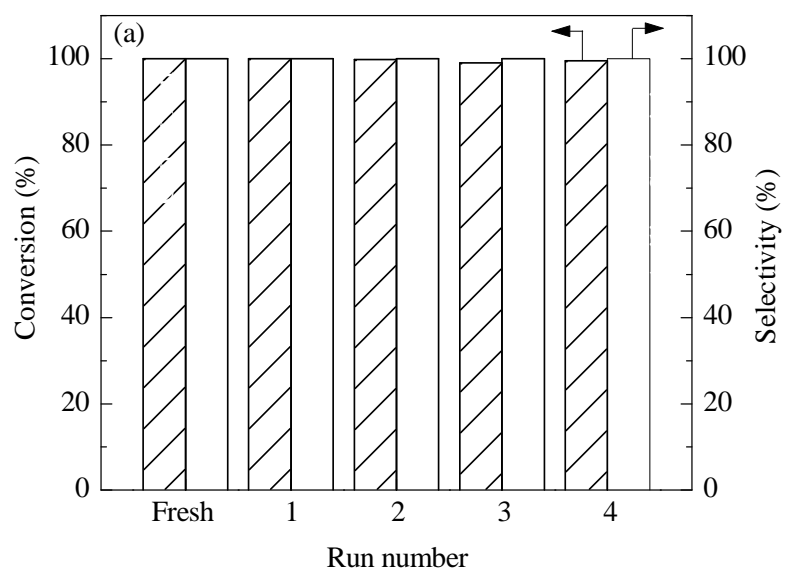

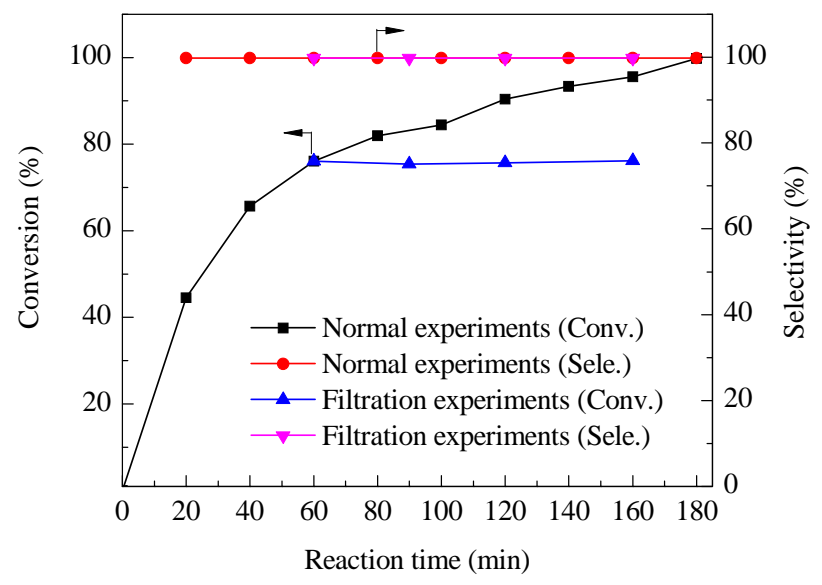

Fig. 7. Reduction of nitrobenzene with $\mathrm{HCOONH}_{4}$. Reaction conditions: nitrobenzene $0.5 \mathrm{mmol}^{\mathrm{HCOONH}} 43.0 \mathrm{mmol}_{4} \mathrm{H}_{2} \mathrm{O} 2.5 \mathrm{~mL}, \mathrm{O}-\mathrm{MoS}_{2} 20 \mathrm{mg}$ $130^{\circ} \mathrm{C}, \mathrm{Ar}$.

Some other Mo-based catalysts were compared with $\mathrm{O}-\mathrm{MoS}_{2}$. Pure $\mathrm{MoO}_{2}$ and $\mathrm{MoO}_{3}$ were inactive for nitrobenzene reduction (Table 2, entries 11 and 12 ). Even the highly dispersed molybdenum oxides on the $2 \mathrm{H}-\mathrm{MoS}_{2}$ support have no activity at all (entries 13 and 14). Thermal treatment in Ar made $\mathrm{O}-\mathrm{MoS}_{2}$ inactive (entry 15). An attempt to post-oxidize the perfect $2 \mathrm{H}-\mathrm{MoS}_{2}$ surface failed to obtain an active catalyst (entry 16), indicating the uniqueness of the present incomplete sulfidation and reduction process during the $\mathrm{O}$-containing $\mathrm{MoS}_{2}$ bulk synthesis. Catalyst hot filtration was also performed (entry 17). No further conversion occurred after the filtration over the next 100 min of reaction at $130{ }^{\circ} \mathrm{C}$ (entry 18), which indicated that the reaction was a heterogeneous catalysis (Figure 7). The spent catalyst was filtered out, washed with ethanol, dried under vacuum, and then used in a new reaction. It was found to be reusable for at least four cycles with comparably good results (entry 19), showing the stability of O-MoS2 (Figure 8).

Two reaction routes for nitrobenzene reduction are widely accepted: the direct route and the condensation route (Scheme 1) $[27,58,59]$. The condensation route involves an azobenzene intermediate. When azobenzene $(0.25 \mathrm{mmol})$ was used as reactant, $\mathrm{O}-\mathrm{MoS}_{2}$ offered $12.5 \%$ conversion at $130{ }^{\circ} \mathrm{C}$ in $3 \mathrm{~h}$. The

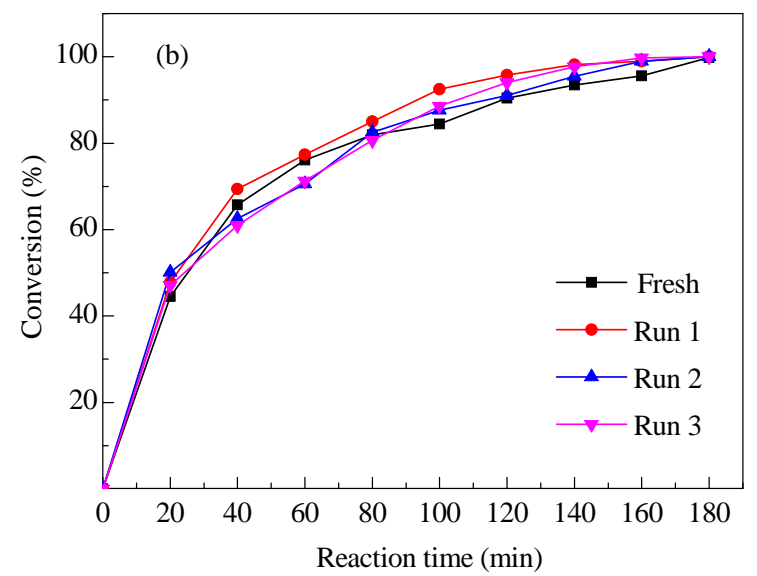

Fig. 8. Reusability of $\mathrm{O}-\mathrm{MoS}_{2}$ in the nitrobenzene reduction reaction. Reaction conditions: nitrobenzene $0.5 \mathrm{mmol}^{\mathrm{HCOONH}} \mathrm{HCO}_{3} 3.0 \mathrm{mmol}^{\mathrm{H}} \mathrm{H}_{2} 2.5 \mathrm{~mL}$ $\mathrm{O}-\mathrm{MoS}_{2} 20 \mathrm{mg}, \mathrm{Ar}, 130^{\circ} \mathrm{C}, 3 \mathrm{~h}$. 


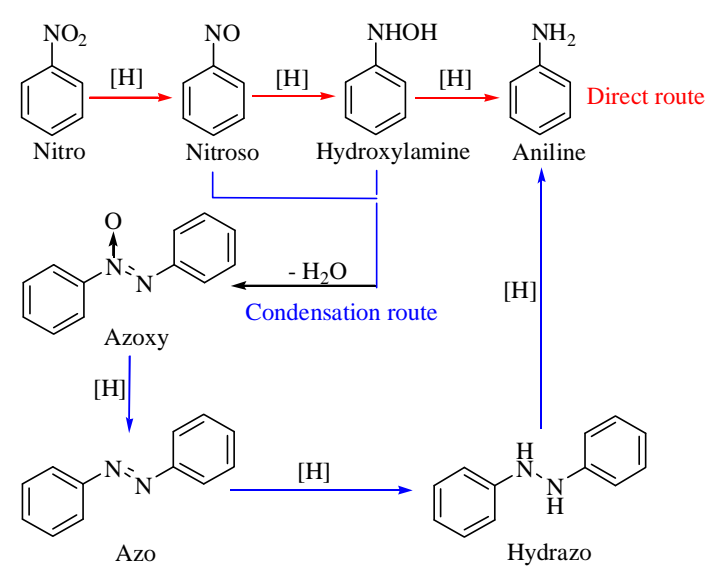

Scheme 1. Reaction network of the nitrobenzene reduction.

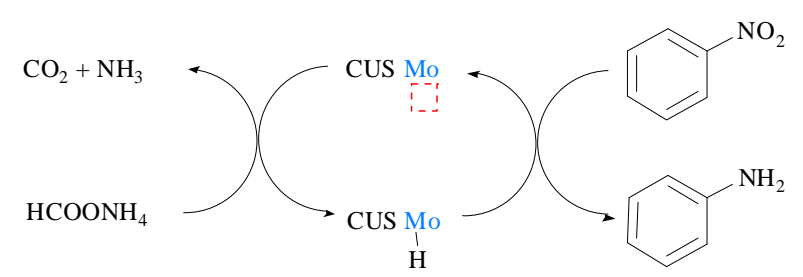

Scheme 2. Possible mechanism of nitrobenzene reduction over the CUS Mo sites on the surface of the $0-\mathrm{MoS}_{2}$.

conversion of $\mathrm{PhNO}_{2}$ over $\mathrm{O}-\mathrm{MoS}_{2}$ was 7 times greater than the azobenzene conversion. Based on the characterization of the catalyst, we believe that the reaction occurred mainly via the direct route with the following mechanism (Scheme 2): (i) $\mathrm{HCOONH}_{4}$ initially adsorbs on the CUS Mo site and generates a Mo-formate intermediate; (ii) the Mo-formate intermediate transforms to molybdenum hydride $(\mathrm{Mo}-\mathrm{H})$ via a $\beta$-hydride elimination [28,36,60], simultaneously releasing a $\mathrm{CO}_{2}$; (iii) finally, the nitro-group is hydrogenated by the Mo- $\mathrm{H}$, and the CUS Mo site is restored to its initial state for the next cycle.

We then explored the substrate scope. $p$-Chloroaniline was obtained in $>99 \%$ GC yield without dehalogenation (Table 3, entry 1). The nitroarenes with $-\mathrm{OH},-\mathrm{CH}_{3},-\mathrm{COCH}_{3}$ and $-\mathrm{OCH}_{3}$ substituents are only slightly soluble in water, so $0.5 \mathrm{wt} \%$ of

\section{Table 3}

Scope of the reduction reaction with ammonium formate in aqueous solution a.

\begin{tabular}{|c|c|c|c|}
\hline Entry & Substrate & Product & GC yield (\%) \\
\hline$\overline{1^{b}}$ & 4-Cl-PhNO 2 & 4-Cl-PhNH 2 & $99(92.1)$ \\
\hline 2 & 4-HO- $\mathrm{PhNO}_{2}$ & 4-HO- $\mathrm{PhNH}_{2}$ & $>99$ \\
\hline 3 & $4-\mathrm{CH}_{3}-\mathrm{PhNO}_{2}$ & 4- $\mathrm{CH}_{3}-\mathrm{PhNH}_{2}$ & $>99$ \\
\hline 4 & 4- $\mathrm{CH}_{3} \mathrm{CO}-\mathrm{PhNO}_{2}$ & 4- $\mathrm{CH}_{3} \mathrm{CO}-\mathrm{PhNH}_{2}$ & 99 (87.2) \\
\hline 5 & 4- $\mathrm{CH}_{3} \mathrm{O}-\mathrm{PhNO}_{2}$ & 4- $\mathrm{CH}_{3} \mathrm{O}-\mathrm{PhNH}_{2}$ & $>99$ \\
\hline 6 & $4-\mathrm{H}_{2} \mathrm{~N}-\mathrm{PhNO}_{2}$ & $4-\mathrm{H}_{2} \mathrm{~N}-\mathrm{PhNH}_{2}$ & $>99$ \\
\hline 7 & $3-\mathrm{NO}_{2}-\mathrm{PhNO}_{2}$ & $3-\mathrm{NH}_{2}-\mathrm{PhNH}_{2}$ & $>99$ \\
\hline 8 & 5- $\mathrm{NO}_{2}$-indole & 5- $\mathrm{NH}_{2}$-indole & 80.6 \\
\hline $9 \mathrm{c}$ & $\mathrm{PhNO}_{2}$ & $\mathrm{PhNH}_{2}$ & 0 \\
\hline 10 & $\mathrm{Ph}-\mathrm{CH}=\mathrm{CH}_{2}$ & $\mathrm{Ph}-\mathrm{C}_{2} \mathrm{H}_{5}$ & 0 \\
\hline 11 & $\mathrm{Ph}-\mathrm{C} \equiv \mathrm{CH}$ & $\mathrm{Ph}-\mathrm{CH}=\mathrm{CH}_{2}$ & 0 \\
\hline 12 & $4-\left(\mathrm{CH}_{3}\right)_{2} \mathrm{~N}-\mathrm{Ph}-\mathrm{CHO}$ & 4- $\left(\mathrm{CH}_{3}\right)_{2} \mathrm{~N}-\mathrm{Ph}-\mathrm{CH}_{3}$ & 0.8 \\
\hline
\end{tabular}

a Reaction conditions: Substrate $0.5 \mathrm{mmol}, \mathrm{H}_{2} \mathrm{O} 3.0 \mathrm{~mL}$ contains $0.5 \mathrm{wt} \%$ of CTAB, $\mathrm{HCOONH}_{4} 3.6 \mathrm{mmol}, \mathrm{O}-\mathrm{MoS}_{2} 20 \mathrm{mg}, 130{ }^{\circ} \mathrm{C}, \mathrm{Ar}, 6 \mathrm{~h}$.

b No CTAB, 3 h. c $2 \mathrm{H}-\mathrm{MoS}_{2} 20 \mathrm{mg}$, with CTAB, 3 h. cetyltrimethyl ammonium bromide (CTAB) relative to the solvent mass was added. By doing so, these nitroarenes were converted to the corresponding arylamines in $>99 \%$ yield without affecting these functional groups (entries 2-5). The isolated yields of $p$-chloroaniline and $p$-acetylaniline were $92.1 \%$ and $87.2 \%$, respectively. Moreover, multiamino aromatic compounds could also be efficiently and selectively produced via the chemoselective reduction of the corresponding nitroarenes or nitroarene (entries 6 and 7). Notably, 0-MoS2 efficiently catalyzed the reduction of a heterocyclic nitroarene to an amine (entry 8). However, it was inactive for the reduction of olefin, alkyne, and carbonyl compounds (entries 10-12) with $\mathrm{HCOONH}_{4}$ at $130{ }^{\circ} \mathrm{C}$. Additionally, $2 \mathrm{H}-\mathrm{MoS}_{2}$ remained catalytically inert in the aqueous solution with CTAB (entry 9).

\subsection{Location of CUS Mo sites}

Next, we quantitatively measured the CUS Mo sites using $\mathrm{NH}_{3}$-TPD (Figure 9). The chemically exfoliated $\mathrm{MoS}_{2}\left(\mathrm{ceMoS}_{2}\right)$ contained more CUS Mo sites $(34.8 \mu \mathrm{mol} / \mathrm{g})$ than $2 \mathrm{H}-\mathrm{MoS}_{2}$ (10.7 $\mu \mathrm{mol} / \mathrm{g})$. In comparison, the amount of CUS Mo sites in O-MoS2 $(226.4 \mu \mathrm{mol} / \mathrm{g})$ was 7 times greater than that of ceMoS 2 . After treatment in Ar at $250{ }^{\circ} \mathrm{C}$, the amount of CUS Mo sites in $0-\mathrm{MoS}_{2}-\mathrm{Ar}$ was remarkably decreased to $11.2 \mu \mathrm{mol} / \mathrm{g}$. This is consistent with the HRTEM observations (Figures 5(f) and $4(\mathrm{~h})$ ), which showed that the lattice matrix became ordered after thermal treatment. In turn, the ordered matrix implies a loss of CUS Mo sites and decreased catalytic activity.

We then established a model to elucidate the location of CUS Mo sites. Here, we assumed that the $\mathrm{MoS}_{2}$ nanosheets had a parallelogram shape and equal edge lengths. The dependence of the edge CUS Mo site ratio (Rn) among the total Mo ions of the $\mathrm{MoS}_{2}$ on the edge length (Ln) is given in Figure 10. By assuming all edge Mo to be CUS sites, $\mathrm{Rn}$ is equal to $(4 n-1) /\left(n^{2}+2 n\right)$, where $\mathrm{n}$ is the number of hexagons at the edge. The CUS Mo site ratio $(R)$ was calculated for each $\mathrm{MoS}_{2}$ on the basis of one CUS Mo site adsorbing one $\mathrm{NH}_{3}$, as given in the inset table of Figure 9. According to the formulae $\mathrm{Rn}=$ $(4 n-1) /\left(n^{2}+2 n\right)$ and $\mathrm{Ln}=0.315 n$, the edge length of $0-\mathrm{MoS}_{2}$

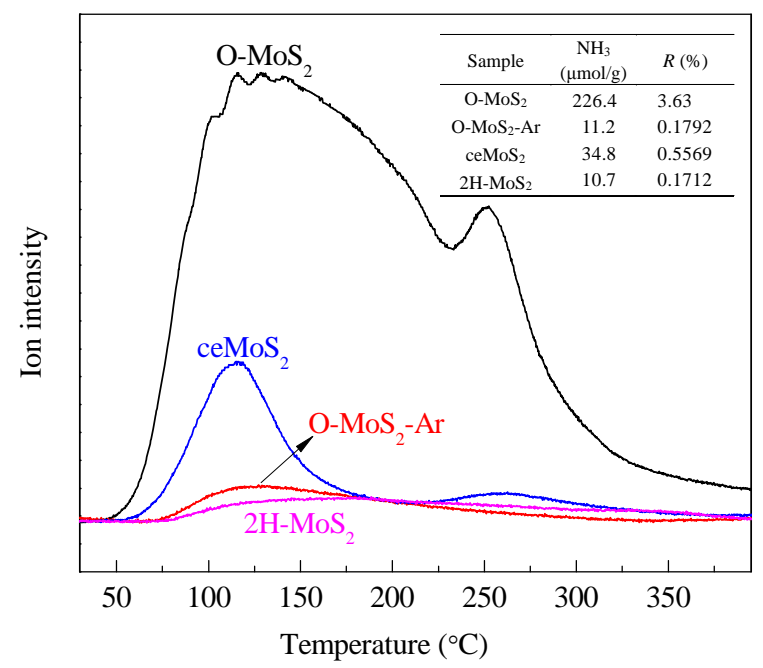

Fig. 9. $\mathrm{NH}_{3}$-TPD profiles of the $\mathrm{MoS}_{2}$ materials. 


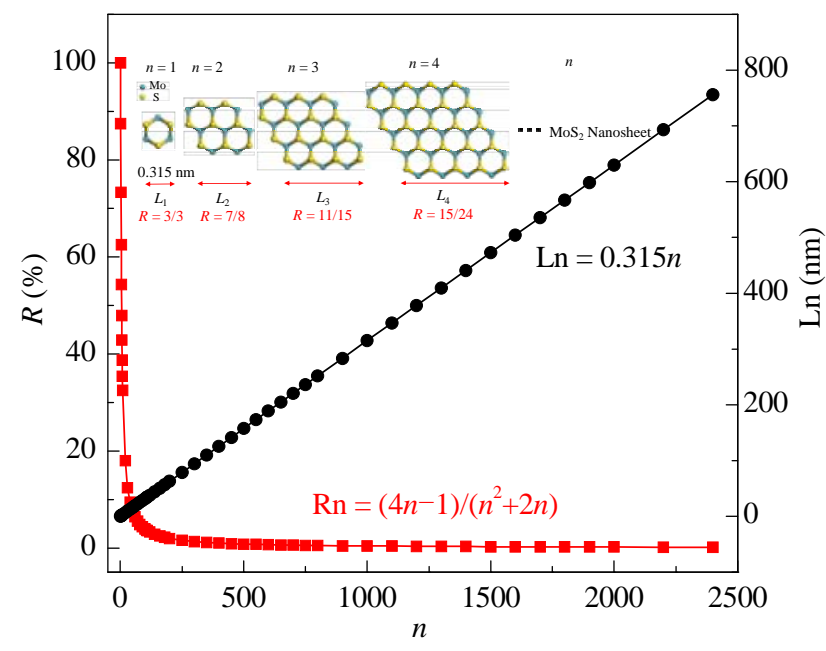

Fig. 10. Ratio model of change in edge sites of $\mathrm{MoS}_{2}$ with edge length.

should be shorter than $34 \mathrm{~nm}$ given that its $R$ is $3.63 \%$. If one CUS Mo site adsorbs two $\mathrm{NH}_{3}$, the edge length of $\mathrm{O}-\mathrm{MoS}_{2}$ should be $69 \mathrm{~nm}$. Actually, its size was much longer than $200 \mathrm{~nm}$ (Figure 5(e)). This inconsistency suggests that only a minor amount of the CUS Mo sites (ca. 5\%) existed at the edge, while the majority were located on the distorted basal planes of the $0-\mathrm{MoS}_{2}$, which is consistent with the HRTEM and $\mathrm{NH}_{3}$-TPD analyses of $\mathrm{O}-\mathrm{MoS}_{2}$ and $\mathrm{O}-\mathrm{MoS}_{2}-\mathrm{Ar}$.

\section{Conclusions}

We have herein reported a strategy for activating catalytically inert $\mathrm{MoS}_{2}$ basal planes into highly active locations for the reduction of nitroarenes to arylamines with formate. The active $\mathrm{O}-\mathrm{MoS}_{2}$ was synthesized via incomplete sulfidation and reduction of the molybdate precursor $\left(\left[\mathrm{Mo}_{7} \mathrm{O}_{24}\right]^{6-}\right)$. The deliberately left Mo-O bonds interrupted the growth of $\mathrm{MoS}_{2}$ layers with a perfect lattice, which induced lattice distortion and defects that exposed extra coordinatively unsaturated Mo sites on the basal planes as catalytically active sites, as confirmed by Raman spectroscopy, HRTEM, XPS, EXAFS, and $\mathrm{NH}_{3}$-TPD. We believe that this MoS2 synthesis method will broaden the applications of $\mathrm{MoS}_{2}$ catalysts from traditional high-temperature gas-phase reactions to mild heterogeneous liquid-phase reactions.

\section{References}

[1] R. V. Jagadeesh, A. E. Surkus, H. Junge, M. M. Pohl, J. Radnik, J. Rabeah, H. M. Huan, V. Schünemann, A. Brückner, M. Beller, Science, 2013, 342, 1073-1076.

[2] A. Corma, P. Serna, Science, 2006, 313, 332-324.

[3] L. He, L. C. Wang, H. Sun, J. Ni, Y. Cao, H. Y. He, K. N. Ean, Angew. Chem. Int. Ed., 2009, 48, 9538-9541.

[4] A. Grirrane, A. Corma, H. Garcia, Science, 2008, 322, 1661-1664.

[5] X. Liu, H. Q. Li, S. Ye, Y. M. Liu, H. Y. He, Y. Cao, Angew. Chem. Int. $E d ., 2014,53,7624-7628$.

[6] R. S. Downing, P. J. Kunkeler, H. van Bekkum, Catal. Today, 1997, $37,121-136$

[7] M. Pietrowski, Green Chem., 2011, 13, 1633-1635.

[8] Z. Y. Sun, Y. F. Zhao, Y. Xie, R. T. Tao, H. Y. Zhang, C. L. Huang, Z. M. Liu, Green Chem., 2010, 12, 1007-1011.

[9] H. S. Wei, X. Y. Liu, A. Q. Wang, L. L. Zhang, B. T. Qiao, X. F. Yang, Y. Q. Huang, S. Miao, J. Y. Liu, T. Zhang, Nat. Commun., 2014, 5, 5634.

[10] A. Corma, C. González-Arellano, M. Iglesias, F. Sánchez, Appl. Catal. A, 2009, 356, 99-102.

[11] A. Corma, P. Serna, H. García, J. Am. Chem. Soc., 2007, 129, 63586359.

[12] T. Fu, P. Hu, T. Wang, Z. Dong, N. H. Xue, L. M. Peng, X. F. Guo, W. P. Ding, Chin. J. Catal., 2015, 36, 2030-2035.

[13] J. R. Li, X. H. Li, Y. Ding, P. Wu, Chin. J. Catal., 2015, 36, 1995-2003.

[14] K. I. Shimizu, Y. Miyamoto, A. Satsuma, J. Catal., 2010, 270, 86-94.

[15] Y. M. Lu, H. Z. Zhu, W. G. Li, B. Hu, S. H. Yu, J. Mater. Chem. A, 2013, 1,3783-3788.

[16] X. F. Yang, A. Q. Wang, B. T. Qiao, J. Li, J. Y. Liu, T. Zhang, Acc. Chem. Res., 2013, 46, 1740-1748.

[17] S. F. Cai, H. H. Duan, H. P. Rong, D. S. Wang, L. S. Li, W. He, Y. D. Li, ACS Catal., 2013, 3, 608-612.

[18] H. S. Wei, X. Wei, X. F. Yang, G. Z. Yin, A. Q. Wang, X. Y. Liu, Y. Q. Huang, T. Zhang, Chin. J. Catal., 2015, 36, 160-167.

\section{Graphical Abstract}

Chin. J. Catal., 2016, 37: 1569-1578 doi: 10.1016/S1872-2067(16)62504-4

\section{Chemoselective transfer hydrogenation to nitroarenes mediated} by oxygen-implanted $\mathrm{MoS}_{2}$

Chaofeng Zhang, Xu Wang, Mingrun Li, Zhixin Zhang, Yehong Wang, Rui Si, Feng Wang*

Dalian Institute of Chemical Physics, Chinese Academy of Sciences; Shanghai Institute of Applied Physics, Chinese Academy of Sciences; University of Chinese Academy of Sciences

We present an efficient approach for the chemoselective synthesis of arylamines from nitroarenes and formate over an oxygen-implanted $\mathrm{MoS}_{2}$ catalyst $\left(\mathrm{O}-\mathrm{MoS}_{2}\right)$. The $\mathrm{O}-\mathrm{MoS}_{2}$ was prepared by incomplete sulfidation and reduction of the ammonium molybdate precursor. $\mathrm{O}-\mathrm{MoS}_{2}$ with abundant CUS Mo sites efficiently catalyzed the chemoselective reduction of nitroarenes to arylamines.

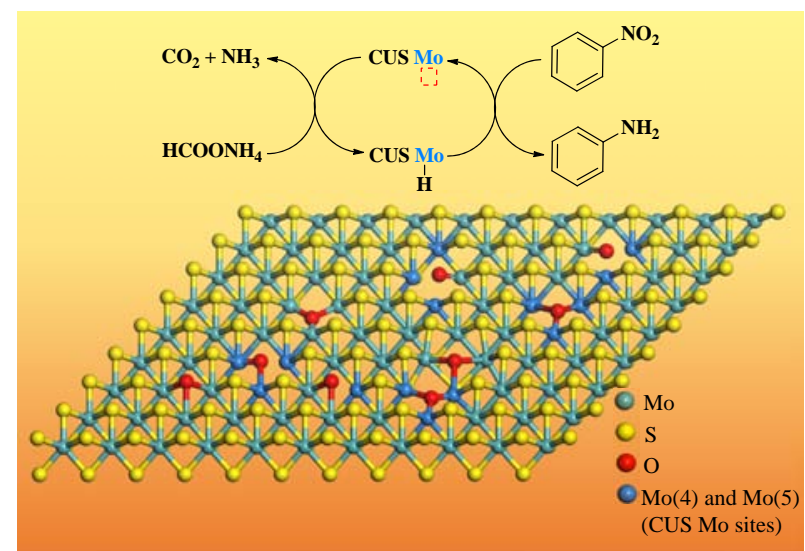


[19] S. P. Jian, Y. W. Li, Chin. J. Catal., 2016, 37, 91-97.

[20] M. Boronat, P. Concepcion, A. Corma, S. Gonzalez, F. Illas, P. Serna, J. Am. Chem. Soc., 2007, 129, 16230-16237.

[21] T. Mitsudome, Y. Mikami, M. Matoba, T. Mizugaki, K. Jitsukawa, K. Kaneda, Angew. Chem. Int. Ed., 2012, 51, 136-139.

[22] A. Noujima, T. Mitsudome, T. Mizugaki, K. Jitsukawa, K. Kaneda, Angew. Chem. Int. Ed., 2011, 50, 2986-2989.

[23] P. S. Kumbhar, J. Sanchez-Valente, F. Figueras, Tetrahedron Lett., 1998, 39, 2573-2574.

[24] Q. X. Shi, R. W. Lu, K. Jin, Z. X. Zhang, D. F. Zhao, Green Chem., 2006, 8, 868-870.

[25] D. Cantillo, M. Baghbanzadeh, C. O. Kappe, Angew. Chem. Int. Ed., 2012, 51, 10190-10193.

[26] F. A. Westerhaus, R. V. Jagadeesh, G. Wienhöfer, M. M. Pohl, J. Radnik, A. E. Surkus, J. Rabeah, K. Junge, H. Junge, M. Nielsen, A. Brückner, M. Beller, Nat. Chem., 2013, 5, 537-543.

[27] H. Z. Zhu, Y. M. Lu, F. J. Fan, S. H. Yu, Nanoscale, 2013, 5, 7219-7223.

[28] C. F. Zhang, J. M. Lu, M. R. Li, Y. H. Wang, Z. Zhang, H. J. Chen, F. Wang, Green Chem., 2016, 18, 2435-2442.

[29] H. Y. Zhou, L. Shi, Q. Sun, Chin. J. Catal., 2012, 33, 1463-1469.

[30] Z. K. Zhao, H. L. Yang, Y. Li, X. W. Guo, Green Chem., 2014, 16, 1274-1281.

[31] A. Boddien, F. Gartner, C. Federsel, P. Sponholz, D. Mellmann, R. Jackstell, H. Junge, M. Beller, Angew. Chem. Int. Ed., 2011, 50, 6411-6414.

[32] X. Liu, S. S. Li, Y. M. Liu, Y. Cao, Chin. J. Catal., 2015, 36, 1461-1475.

[33] R. V. Jagadeesh, D. Banerjee, P. B. Arockiam, H. Junge, K. Junge, M. M. Pohl, J. Radnik, A. Brückner, M. Beller, Green Chem., 2015, 17, 898-902.

[34] A. Saha, B. Ranu, J. Org. Chem., 2008, 73, 6867-6870.

[35] D. C. Gowda, A. S. P. Gowda, A. R. Baba, S. Gowda, Synth. Commun., 2000, 30, 2889-2895.

[36] I. Sorribes, G. Wienhofer, C. Vicent, K. Junge, R. Llusar, M. Beller, Angew. Chem. Int. Ed., 2012, 51, 7794-7798.

[37] T. F. Jaramillo, K. P. Jorgensen, J. Bonde, J. H. Nielsen, S. Horch, I. Chorkendorff, Science, 2007, 317, 100-102.

[38] H. I. Karunadasa, E. Montalvo, Y. J. Sun, M. Majda, J. R. Long, C. J. Chang, Science, 2012, 335, 698-702.

[39] J. Kibsgaard, Z. B. Chen, B. N. Reinecke, T. F. Jaramillo, Nat. Mater., 2012, 11, 963-969.

[40] R. J. Smith, P. J. King, M. Lotya, C. Wirtz, U. Khan, S. De, A. O'Neill, G. S. Duesberg, J. C. Grunlan, G. Moriarty, J. Chen, J. Z. Wang, A. I. Minett, V. Nicolosi, J. N. Coleman, Adv. Mater., 2011, 23, 3944-3948.

[41] Z. Y. Zeng, T. Sun, J. X. Zhu, X. Huang, Z. Y. Yin, G. Lu, Z. X. Fan, Q. Y.
Yan, H. H. Hng, H. Zhang, Angew. Chem. Int. Ed., 2012, 51, 9052-9056.

[42] K. G. Zhou, N. N. Mao, H. X. Wang, Y. Peng, H. L. Zhang, Angew. Chem. Int. Ed., 2011, 50, 10839-10842.

[43] R. Tokarz-Sobieraj, R. Grybos, M. Witko, Appl. Catal., A, 2011, 391, 137-143.

[44] B. Radisavljevic, A. Radenovic, J. Brivio, V. Giacometti, A. Kis, Nat. Nanotech., 2011, 6, 147-150.

[45] J. F. Xie, J. J. Zhang, S. Li, F. Grote, X. D. Zhang, H. Zhang, R. X. Wang, Y. Lei, B. C. Pan, Y. Xie, J. Am. Chem. Soc., 2013, 135, 17881-17888.

[46] J. F. Xie, H. Zhang, S. Li, R. X. Wang, X. Sun, M. Zhou, J. F. Zhou, X. W. Lou, Y. Xie, Adv. Mater., 2013, 25, 5807-5813.

[47] J. Deng, H. B. Li, J. P. Xiao, Y.C. Tu, D. H. Deng, H. X. Yang, H. F. Tian, J. Q. Li, P. J. Ren, X. H. Bao, Energy Environ. Sci., 2015, 8, 1594-1601.

[48] Q. F. Gong, L. Cheng, C. H. Liu, M. Zhang, Q. L. Feng, H. L. Ye, M. Zeng, L. M. Xie, Z. Liu, Y. G. Li, ACS Catal., 2015, 5, 2213-2219.

[49] S. S. Chou, B. Kaehr, J. Kim, B. M. Foley, M. De, P. E. Hopkins, J. X. Huang, C. J. Brinker, V. P. Dravid, Angew. Chem. Int. Ed., 2013, 52, 4160-4164.

[50] Y. M. Sun, X. L. Hu, W. Luo, Y. H. Huang, ACS Nano, 2011, 5, 7100-7107.

[51] C. Lee, H. Yan, L. E. Brus, T. F. Heinz, J. Hone, S. Ryu, ACS Nano, 2010, 4, 2695-2700.

[52] H. Li, Q. Zhang, C. C. R. Yap, B. K. Tay, T. H. T. Edwin, A. Olivier, D. Baillargeat, Adv. Funct. Mater., 2012, 22, 1385-1390.

[53] L. Seguin, M. Figlarz, R. Cavagnat, J. C. Lassègues, Spectrochim. Acta A, 1995, 51, 1323-1344.

[54] X. G. Guo, G. Z. Fang, G. Li, H. Ma, H. J. Fan, L. Yu, C. Ma, X. Wu, D. H. Deng, M. M. Wei, D. L. Tan, R. Si, S. Zhang, J. Q. Li, L. T. Sun, Z. C. Tang, X. L. Pan, X. H. Bao, Science, 2014, 344, 616-619.

[55] J. Ke, W. Zhu, Y. Y. Jiang, R. Si, Y. J. Wang, S. C. Li, C. H. Jin, H. C. Liu, W. G. Song, C. H. Yan, Y. W. Zhang, ACS Catal., 2015, 5, 5164-5173.

[56] W. W. Wang, P. P. Du, S. H. Zou, H. Y. He, R. X. Wang, Z. Jin, S. Shi, Y. Y. Huang, R. Si, Q. S. Song, C. J. Jia, C. H. Yan, ACS Catal., 2015, 5, 2088-2099.

[57] Q. Y. Bi, X. L. Du, Y. M. Liu, Y. Cao, H. Y. He, K. N. Fan, J. Am. Chem. Soc., 2012, 134, 8926-8933.

[58] F. Haber, Z. Elektrochem. Angew. Phys. Chem., 1898, 4, 506-513.

[59] A. Corma, P. Concepcion, P. Serna, Angew. Chem. Int. Ed., 2007, 46, 7266-7269.

[60] A. Boddien, D. Mellmann, F. Gärtner, R. Jackstell, H. Junge, P. J. Dyson, G. Laurenczy, R. Ludwig, M. Beller, Science, 2011, 333, 1733-1736.

\title{
氧掺入 $\mathrm{MoS}_{2}$ 调节芳香硝基化合物选择性转氢还原
}

\author{
张超锋 ${ }^{\mathrm{a}, \mathrm{b}}$, 王 旭 ${ }^{\mathrm{c}}$, 李名润 ${ }^{\mathrm{a}}$, 张志鐐 ${ }^{\mathrm{a}}$, 王业红 ${ }^{\mathrm{a}}$, 司 锐 ${ }^{\mathrm{c}}$, 王 峰 ${ }^{\mathrm{a},{ }^{*}}$ \\ a中国科学院大连化学物理研究所催化基础国家重点实验室, 洁净能源国家实验室 (筹), 辽宁大连 116023 \\ b 中国科学院大学, 北京 100049 \\ c中国科学院上海应用物理研究所, 上海同步辐射光源, 上海 201204
}

摘要: 芳香胺类化合物及其衍生物是一类重要的有机合成中间体, 广泛应用于染料、农药、医药及其他精细化学品. 目前
催化芳香硝基化合物还原制备芳香胺的多相催化体系多使用含有 $\mathrm{d}_{6}-\mathrm{d}_{10}$ 贵金属以及高活性 Ni 的催化剂. 为了提高反应的
选择性, 金属纳米颗粒的尺寸控制、合金效应、金属载体强相互作用、溶剂以及添加剂的篮选等不同手段被采用. 考到
该类催化剂复杂的制备方法以及易氧化的性质, 近年来稳定高效的非贵金属体系的开发得到了广泛关注.
$\mathrm{MoS}_{2}$ 是一类重要的高温加氢催化剂, 不饱和的 Mo 位点 (CUS Mo) 被认为在催化过程中起到了关键性作用. 但是理论 
与实践已经证明, 作为代表性的二维材料, $\mathrm{MoS}_{2}$ 的活性位点多集中于层状结构的边楞结构处. 占有最大暴露面积的基面结 构因为稳定的 Mo-S 化学键组成在化学反应中多表现为催化惰性. 通过剥离的手段可以有效提升活性位点的数目, 但新增 的活性位点仍然多集中于层状结构的边楞结构处而不是基面. 在 $\mathrm{MoS}_{2}$ 与 $\mathrm{MoO}_{2}$ 结构中 $\mathrm{Mo}-\mathrm{S}$ 和 $\mathrm{Mo}-\mathrm{O}$ 的键长不同, 同时 $\mathrm{S}$ 和 $\mathrm{O}$ 的配位形式也不同. 可以预见的是, 如果 $\mathrm{MoS}_{2}$ 结构中的一部分 $\mathrm{S}$ 元素被 $\mathrm{O}$ 元素取代, 在这样的材料中将会出现大 量缺陷以及活性 CUS Mo 结构.

结合先前关于硫化锄材料的制备方法, 我们通过部分硫化还原 $\left[\mathrm{Mo}_{7} \mathrm{O}_{24}\right]^{6-}$ 前驱物的方法制备了氧掺杂的 $\mathrm{MoS}_{2}$ 材料 (标

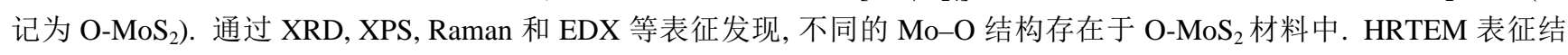
果显示, $\mathrm{O}-\mathrm{MoS}_{2}$ 表面存在着丰富的结构缺陷. EXAFS 结果显示, $\mathrm{O}^{-\mathrm{MoS}_{2}}$ 材料中可能含有四配位以及五配位的 CUS Mo 结 构. 以甲酸铵还原硝基苯为探针反应检测了 CUS Mo 结构. 发现 $\mathrm{O}-\mathrm{MoS}_{2}$ 可以在水相条件下高效催化芳香硝基化合物还 原生成相应的芳香胺, 且催化剂稳定, 可以多次循环使用. 结合对照不同催化剂的 $\mathrm{NH}_{3}-\mathrm{TPD}$ 数据以及 $\mathrm{MoS}_{2}$ 结构模型, 我

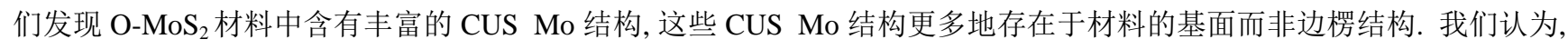
对于该类掺杂 $\mathrm{MoS}_{2}$ 材料的制备及结构表征将有利于拓宽 $\mathrm{MoS}_{2}$ 催化剂从高温气相反应到温和液相反应中的应用.

关键词: 二硫化钿; 不饱和 Mo 位点; 芳香硝基化合物; 转氢氢化; 甲酸盐; 多相催化

收稿日期: 2016-06-03. 接受日期: 2016-07-11. 出版日期: 2016-09-05.

*通讯联系人. 电话/传真: (0411)84379762; 电子信箱: wangfeng@dicp.ac.cn

基金来源：国家自然科学基金 (21422308, 21403216, 21273231); 大连市优秀青年基金 (2014J11JH126).

本文的英文电子版由Elsevier出版社在ScienceDirect上出版(http://www.sciencedirect.com/science/journal/18722067). 